\title{
PERANCANGAN APLIKASI E-COMMERCE DENGAN SISTEM REKOMENDASI ITEM-BASED COLLABORATIVE FILLTERING
}

\author{
Rio Oktora \\ Wiwin Susanty \\ Program Studi Sistem Informasi Fakultas Ilmu Komputer, \\ Universitas Bandar Lampung \\ Jl. Zainal Abidin Pagar Alam No. 26 Labuhan Ratu \\ Email : Wien_adetha28@yahoo.com,
}

\begin{abstract}
PD Damai Motors is one company in the town of Bandar Lampung engaged in the sale of spare parts, however, the system is running right now, there are still many problems that occur both on the vendor and on the part of consumers, especially outside the city of Bandar Lampung. The vendor has not had a special media to promote a product - products and recording sales transactions reports are done manually using only existing proof of the transaction. And consumers still have to directly come to the store if you want to get information about products and want to order the products according to the desired design, as well as the consumer should contact the vendor via sms / call if you want to know the progress of the production order. Scientific report will describe and explain the design Application E-Commerce system with Item-Based Collaborative Filltering clearly so that can know the location of the problem. In analyzing the system, the authors use analytical tools such as Document Flow Diagram (flowchart) and Unified Modeling Language $(U M L) X V+60+$ Attachment Refrences
\end{abstract}

Keyword : Recommendation, System Recommendation, CMS , e-Commerce

\section{PENDAHULUAN}

\subsection{Latar Belakang}

Dengan berbekalkan motivasi tersebut maka teknologi computer pun menjadi pilihan yang semakin dicari dan dikembangkan setiap detik , menit ,dan jamnya. Salah satunya adalah penggunaan teknologi untuk memperbaiki dan menyempurnakan sistem yang beredar dalam peradaban saat ini . salah satunya adalah sistem yang lazim kita lihat dan di gunakan untuk penjualan barang secara online ( $e$-Commerce ).

Perancangan aplikasi e-Commerce penjualan berdasarkan sistem rekomendasi ini menggunakan tekhnik Collaborative Filtering (CF) dengan alasan bahwa Collaborative Filtering merupakan tekhnik yang sukses dan paling banyak digunakan dalam pengembangan sistem rekomendasi sampai saat ini.Item-based Collaborative Filtering (IBCF) adalah salah satu pendekatan paling menjanjikan dan sering digunakan dalam sistem rekomendasi secara umum.

Collaborative Filtering Rekomendasi collaborative filtering adalah teknik yang paling banyak digunakan pada sistem rekomendasi. Seperti namanya, collaborative filtering bekerja dengan cara menjumlahkan rating atau pilihan dari suatu produk, menemukan profil / pola pengguna dengan melihat history rating yang diberikan pengguna, dan menghasilkan suatu rekomendasi baru berdasarkan perbandingan antar pola pengguna. Biasanya nilai rating dapat berupa binary (suka/tidak suka) atau voting. ( $\mathrm{Xu}$ dkk, 2010:169-170 )

Item Based Collaborative Filtering Prinsip dasar dari algoritma ini adalah menghitung tingkat kesamaan antara beberapa produk yang berbeda berdasarkan penilaian pengguna ( Meliana Christianti, Christian Hadiguna 2011:5-10)

\subsection{Permasalahan Penelitian Identifikasi Masalah}

PD Damai Motor belum mempunyai website e-Commerce untuk mempromosikan produk nya .Konsumen masih harus langsung datang ke ke tempat apabila ingin mendapatkan informasi produk dan hendak memesan produk sesuai dengan yang di inginkan. Konsumen harus menghubungi pihak PD Damai Motor via sms / telepon jika ingin mengetahui perkembangan produksi atas pesanannya

\section{Batasan Masalah}

Mengingat keterbatasan waktu pada penelitian ini, maka penelitian ini dibatasi hanya pada lingkup perancangan aplikasi e-Commerce sesuai dari rating pada PD Damai Motor untuk memberikan suatu pencerahan alternatif dan membantu penjualan barang demi kemajuan bersama pada PD.Damai Motor 


\section{Rumusan Masalah}

Berdasarkan masalah penelitian di atas, maka dalam penelitian ini , maka permasalahan yang dihadapi yakni sebagai berikut :Apakah aplikasi e-Commerce dengan sistem rekomendasi berbasis Item-Based Collaborative Filtering ini sudah dapat membantu dalam masalah pemesanan ,penjualan barang , informasi perkembangan pemesanan, serta perekomendasi barang hingga spesifikasi barang pada PD. Damai Motor ?."

\section{Hipotesis}

Berdasarkan uraian pada latar belakang dan pokok permasalahan diatas maka dapat ditarik satu hipotesis sebagai berikut :"Diharapkan bahwa aplikasi e-Commerce dengan sistem rekomendasi Item-Based Collaborative Filltering akan sangat membantu dalam mempromosikan serta memperluas market pada PD. Damai Motor"

\subsection{Tinjauan Pustaka}

Tinjauan pustaka diambil dari beberapa buku, jurnal dan artikel yang berhubungan dengan penelitian ini adalah sebagai berikut: Penelitian yang dilakukan oleh Tidian Galih , Aris Sugiharto dan Mustafid ( Universitas Diponegoro, Semarang, Indonesia), tahun 2010, dengan judul "Rancang Bangun Portal eCommerce Semarang Handycraft Berorientasi Objek". Penelitian ini membahas tentang penggunaan Aplikasi e-Commerce untuk membangun portal e-Commerce yang dapat dipakai menjadi salah satu media promosi, karena penggunaan internet sekarang sebagai media teknologi informasi dapat membantu dalam media promosi.

Penelitian yang dilakukan oleh Warih Maharani dan Yanuar Firdaus AW (Departemen Teknik Informatika, Institut Teknologi Telkom , Bandung, Indonesia ), tahun 2008, dengan judul "Analisis Semantic Similarity Pada Item-Based Recomender Sistem". Penelitian ini membahas tentang program yang dapat digunakan untuk memprediksi sebuah item berdasarkan informasi yang diperoleh dari user.

Penelitian yang dilakukan oleh Wiranto dan Winarko (Jurusan Tekhnik Informatika dan Program Studi Ilmu Komputer, Universitas Sebelas Maret, dan Universitas Gajah Mada Yogyakarta , Indonesia ), tahun 2010, dengan judul "Konsep Multicriteria Collaborative Filtering untuk perbaikan rekomendasi". Penelitian ini membahas tentang sarana untuk membantu pencari informasi yang belum memiliki refrensi diperlukan alat bantu recommender system.

Penelitian yang dilakukan oleh Fauzi Hermawan , Risnandar,ST MT dan Tora Fahrudin (Program Studi Manajemen Informatika, Politeknik Telkom, Bandung,) tahun 2010, dengan judul penelitian "Aplikasi e-Commerce untuk Factory Outet". Penelitian ini membahas tentang pengimplementasikan pembanguna website Blackjack dikota Bandung untuk menjadi sarana promosi.

Penelitian yang dilakukan oleh Meliana Christanti dan Christian Hadiguna (Jurusan S1 Tekhnik Informatika ,Fakultas Teknologi Informasi , Universitas Kristen Maranatha Bandung, Indonesia ), tahun 2011, dengan judul "Aplikasi e-Commerce dengan Sistem Rekomendasi Berbasis Collaborative Filltering pada Toko Komputer Ekaria”. Penelitian ini membahas tentang cara mengelola data pelanggan yang terdaftar dalam aplikasi $e$ Commerce.

Penelitian yang dilakukan oleh Lei Ren dan Junzhong Gu, Weiwei Xia (Departement of Computer Science \& Technology, Shangai Normal University , East China Normal University ,Shanghai , China ), tahun 2011, dengan judul "An Item-based Collaborative Filtering Approach based on Balanced Rating Prediction". Penelitian ini membahas tentang aplikasi recommender sistem berdasarkan Itembased Collaborative Filtering Balanced Rating Prediction.

Buku yang ditulis oleh Michael D. Ekstrand, John T. Riedl dan ,Joseph A. Konstan, tahun 2010, dengan judul "Collaborative Filltering Recomender System”. Buku ini membahas tentang metode dari Collaborative Filltering mengevaluasi Recomender Sistem .

Buku yang ditulis oleh Developers DevZone, tahun 2011, dengan judul "Building e-Commerce Applications ". Buku ini membahas tentang cara membuat atau membangun aplikasi eCommerce. 


\subsection{Landasan Teori}

\subsubsection{Pengertian Perancangan}

Perancangan merupakan tahap persiapan untuk rancang bangun implementasi suatu web, yang menggambarkan bagaimana suatu web dibentuk yang dapat berupa penggambaran, perencanaan dan pembuatan sketsa atau pengaturan dari beberapa elemen terpisah ke dalam satu kesatuan yang utuh dan berfungsi termasuk mengkonfigurasikan komponenkomponen perangkat lunakdan perangkat keras dari suatu web.( Dr. Azhar Susanto, MBus, 2004:p51)

\subsubsection{Pengertian Aplikasi}

Aplikasi adalah software yang dibuat oleh suatu perusahaan komputer untuk mengerjakan tugas-tugas tertentu, misalnya Microsoft Word, Microsoft Excel. Dhanta 2009:p32 )

\subsubsection{Pengertian E-Commerce}

Electronic Commerce (Perniagaan Elektronik), sebagai bagian dari Electronic Business (bisnis yang dilakukan dengan menggunakan electronic transmission), oleh para ahli dan pelaku bisnis dicoba dirumuskan definisinya. Secara umum e commerce dapat didefinisikan sebagai segala bentuk transaksi perdagangan/perniagaan barang atau jasa (trade of goods and service) dengan menggunakan media elektronik.

e-Commerce adalah penggunaan jaringan computer untuk melakukan komunikasi bisnis dan transaksi komersial. Kemudian di website e-Commerce Net, e-Commerce di definisikan sebagai kegiatan menjual barang dagangan atau jasa melalui internet. Seluruh komponen yang terlibat dalam bisnis praktis diaplikasikan disini. Seperti produk yang tersedia , cara pembayaran, jaminan atas produk yang dijual, cara promosi, dan sebagainya, seperti customer service, produk yang tersedia, cara pembayaran, jaminan atas produk yang dijual, cara promosi dan sebagainya. Seluruh definisi yang dijelaskan diatas pada dasarnya memliki kesamaan yang mencakup komponen transaksi ( pembeli , penjual , barang, jasa dan informasi ) subyek dan obyek yang terlibat serta media yang digunakan ( dalam hal ini adalah internet ) (Yun Gao 2005:p35)

\section{A. Keuntungan e-Commerce}

Berikut adalah beberapa keunggulan e-commerce

tidak mengenal adanya batasan tempat karena transaksi bisa terjadi walaupun konsumen dan penjual berada di tempat yangberlainan. Mengefisiensikan waktu karena tidak mengenal batasan atau setiap transaksi e commerce bisa dilakukan selama 24 jam. Lebih sedikitnya pegawai yang dibutuhkan untuk melakukan transaksi sehingga dapat mengikis anggaran pengeluaran perusahaan penjual. (Sidik 2003:p5)

\section{B. Kelemahan e-Commerce}

Sering terjadinya penipuan seperti fiktif credit card, atau terkadang penipuan penjual terhadap pelanggan karena hukum yang mengatur tentang e-commerce masih belum terlalu berkembang.

Konsumen tidak dapat melihat langsung kondisi barang yang akan dibeli Mempersempit lapangan pekerjaan karena industri e-commerce tidak membutuhkan banyak pegawai untuk melayani transaksi.(Sidik 2003:p5)

\subsubsection{Pengertian Sistem}

Pengertian sistem menurut beberapa pakar antara lain adalah sebagai berikut: "Sistem adalah elemen-elemen yang saling berhubungan membentuk suatukesatuan atau organisasi”. ( Amsyah 2000 : p4 ).

\section{A. Model Fungsi Sistem Rekomendasi}

Memformulakan masalah rekomendasi dengan mengasumsikan fungsi kegunaan (utility function) rec yang merupakan ukuran kegunaan dari item untuk pengguna (user) . dimana adalah total order dengan range yang jelas. (Admovicius dan Tuzhilin 2005 p:31 )

\section{B. Metode Sistem Rekomendasi}

Ada beberapa metode atau teknik yang digunakan dalam sistem rekomendasi. Setiap metode disesuaikan dengan permasalahan dalam menghasilkan sebuah informasi yang sesuai. Belka dan Plößnig (2004) menyatakan metode atau pendekatan yang dipilih pada sistem rekomendasi bergantung pada permasalahan yang akan diselesaikan, teknik rekomendasi yang berbeda-beda digunakan untuk aplikasi yang berbeda, dasar dari suatu tujuan dan objektif dari sebuah aplikasi. Dari penelitian terbaru metode atau teknik rekomendasi memiliki beberapa sejumlah kemungkinan klasifikasi (Adomavicius \& Tuzilin., 2005).

Berdasarkan metode rekomendasi yang sering digunakan, sistem rekomendasi dibagi dalam beberapa klasifikasi yaitu: content- 
based recommendation, collaborative-based recommendation dan hybrid-based recommendation dan beberapa peneliti menambahkan metode knowledge based recommendation

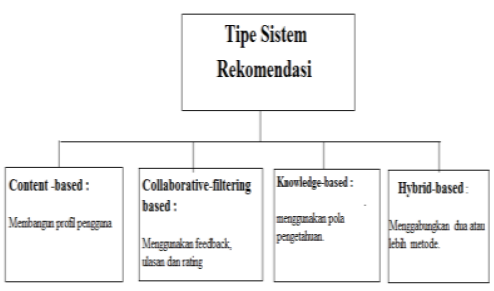

Gambar 2.1 Tipe Sistem Rekomendasi

\subsubsection{Content-Based Recommendation}

Content-based recommendation adalah hasil dari penelitian penyaringan informasi dalam sistem berbasis konten. ( Bogers \& Bosh (2007)

Sistem rekomendasi berbasis konten dimulai dengan memahami kebutuhan user (pengguna), preferensi dan kendala jika ada. Informasi ini digabungkan dengan log dari interaksi user sebelumnya (jika ada) untuk membangun profil pengguna (Sharda N., 2007).

Proses yang dilakukan dalam contentbased recommendation yaitu melalui informasi retrieval dan sistem filtering informasi yang menampilkan keseluruhan perhitungan dari hubungan tunggal descriptor $\mathrm{x}$ object. Objek dapat berupa dokumen teks dan descriptor dapat berupa kata kunci. Gambar 2.2 berikut menunjukan dua entitas dalam relasi antara descriptor dan object ( Baudisch, P 2000 )

\subsubsection{Collaborative-Based Recommendation}

Adomavicius \& Tuzilin (2005) menyatakan sistem collaborative-based recommendation adalah metode yang digunakan untuk memprediksi kegunaan item berdasarkan penilaian pengguna sebelumnya. Metode ini merekomendasikan itemitem yang dipilih oleh pengguna lain dengan kemiripan model item dari pengguna saat ini (Sebastia, L et al., 2009). descriptor matches object Sistem rekomendasi berbasis kolaboratif (collaborative-based) dibuat untuk mengatasi kelemahan dari sistem rekomendasi berbasis konten (content-based) yaitu:

a. Pendekatan collaborative dapat bekerja dalam domain dimana terdapat sedikit content yang berasosiasi dengan item atau ditempat dimana content sulit dianalisis menggunakan komputer seperti ide, masukkan atau opini sehingga menjadi reliable. b. Pendekatan collaborative mempunyai kemampuan untuk menyediakan rekomendasi yang tidak terduga atau tidak disengaja, misalnya dapat merekomendasikan item yang relevan kepada pengguna sekaligus tidak mengandung content dari profil pengguna tersebut.

Berikut merupakan tabel metode collaborative-based recommendation menurut Adomavicius \& Tuzilin (2005) :

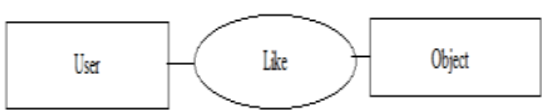

Gambar 2.3 Model hubungan entitas dalam collaborative-based system

\subsubsection{Hybrid-based recommendation}

Hybrid recommender system digunakan untuk menggambarkan setiap sistem rekomendasi yang menggabungkan beberapa teknik rekomendasi untuk menghasilkan sebuah output (Burke, R.,2007).

Adomavicius \& Tuzilin (2005) menyatakan beberapa sistem rekomendasi menggunakan metode hybrid untuk menggabungkan metode content-based dan collaborative untuk membantu keterbatasan yang terdapat pada kedua metode tersebut.

Li,Qing dan Kim, Byeong Man (2002) terdapat beberapa cara penggabungan yang dapat dilakukan dalam metode hybrid yaitu :

1. Penggabungan secara Liner (Linier Combination)

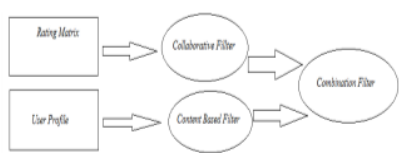

2. Penggabungan secara Sekuensial (Sequential Combination)

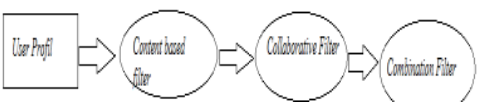

3. Ppenggabungan secara Item-based Clustering Hybrid Method (ICHM)

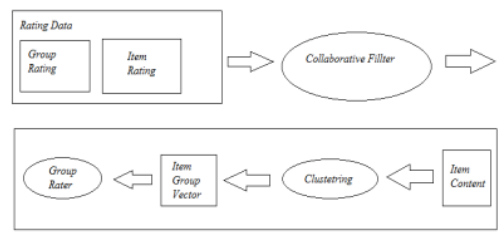

Gambar 2.6 Item-based Clustering Hybrid Method 
Burk, R. (2002) memperkenalkan taxonomy untuk sistem rekomendasi hybrid. taxonomy ini diklasifikasikan ke dalam tujuh kategori, yaitu:

a. Weighted hybrid : Nilai komponen dari sistem rekomendasi yang berbeda digabungkan secara numerik atau menggunakan algoritma linier.

b. Switching hybrid : Sistem memilih komponen-komponen dari setiap rekomendasi dan menerapkan komponen yang dipilih.

c. Mixed hybrid : Rekomendasi dari berbagai sistem rekomendasi disajikan bersama

d. Feature Combination : Fitur-fitur yang berasal dari berbagai sumber pengetahuan digabungkan dan diberikan algoritma rekomendasi

e. Feature Augmentation : merupakan salah satu teknik rekomendasi yangdigunakan untuk menghitung sebuah fitur atau sekumpulan fitur yang kemudian menjadi bagian yang dimasukkan ke teknik berikutnya.

f. Cascade : merupakan rekomendasi yang memiliki prioritas tinggi sebagai solusi pemecahan masalah dalam melakukan perbaikan

g. Meta-level : merupakan salah satu teknik rekomendasi yang diterapkan dan menghasilkan beberapa jenis model, yang kemudian digunakan sebagai input oleh teknik berikutnya

Berikut ini merupakan gambar model hubungan entitas dari metode hybrid ( Baudisch P (2000)

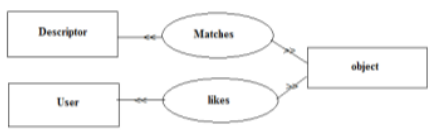

Gambar 2.7 Model hubungan entitas dalam hybrid system

\subsection{Collaborative Filtering ( $\mathrm{CF}$ )}

Rekomendasi Collaborative Filtering adalah tekhnik yang paling banyak digunakan pada sistem rekomendasi. Seperti nama nya, Collaborative Filtering bekerja dengan cara menjumlahkan rating atau pilihan dari suatu produk. Menemukan profil / pola pengguna dengan melihat history rating yang diberikan pengguna, dan menghasilkan suatu rekomendasi baru berdasarkan perbandingan antar pola pengguna.

\subsubsection{User Based Collaborative Filtering}

Prinsip dasar dari user-based collaborative filtering adalah memberikan rekomendasi berdasarkan opini pengguna lain yang memiliki kesukaan yang sama dengan pengguna ( Meliana Christiani , Christian Hadiguna 2011: p157 - 175 )

2.3.2 Item Based Collaborative Filtering

Prinsip dasar dari algoritma ini adalah menghitung tingkat kesamaan antara beberapa produk yang berbeda berdasarkan penilaian pengguna ( Meliana Christiani , Christian Hadiguna 2011: p157 - 175 )

\subsection{Unified Modeling Language (UML)}

Unified Modeling Language (UML) merupakan satu kumpulan konvensi pemodelan yang digunakan untuk menentukan atau menggambarkan sebuah sistem software yang terkait dengan objek (Whitten L. Jeffery et al, 2004). Sementara menurut Henderi (2007: 4) . Bahasa Pemodelan UML lebih cocok untuk pembuatan perangkat lunak dalam bahasa pemrograman berorientasi objek $(\mathrm{C}+$, Java, VB.NET), namun demikiantetap dapat digunakan pada bahasa pemrograman prosedural (Ziga Turck, 2007)

UML berfungsi sebagai jembatan dalam mengkomunikasikan beberapa aspek dalam sistem melalui sejumlah elemen grafis yang bisa dikombinasikan menjadi diagram.

(Henderi et al, 2008:71):

\subsubsection{Diagram Dasar Dalam Unified Modeling Language (UML)}

Berikut ini adalah penjelasan mengenai berbagai diagram UML serta tujuannya:

\section{Model Use Case Diagram}

Use Case Diagram secara grafis menggambarkan interaksi antara sistem, sistem eksternal, dan pengguna. Dengan kata lain Use Case diagram secara grafis mendeskripsikan siapa yang akan menggunakan sistem dan dalam cara apa pengguna (user) mengharapkan interaksi dengan sistem itu. Use Case secara naratif digunakan untuk secara tekstual menggambarkan sekuensi langkah-langkah dari setiap interaksi.

2. Diagram Struktur Statis

UML menawarkan dua diagram untuk memodelkan struktur statis sistem informasi, yaitu:

a. Class Diagram: menggambarkan struktur object sistem. Diagram ini menunjukan class object yang menyusun sistem dan juga hubungan antara class object tersebut 
b. Object Diagram: serupa dengan class diagram, tetapi object diagram memodelkan isntance object actual dengan menunjukan nilai-nilai saat ini dari atribut instance.

\section{Diagram Interaksi}

Diagram interaksi memodelkan sebuah interaksi, terdiri dari satu set objek, hubungan-hubungannya, dan pesan yang terkirim di antara objek.

a. Diagram rangkaian / Sequence Diagram: secara grafis menggambarkan bagaimana objek berinteraksi dengan satu sama lain melalui pesan pada sekuensi sebuah use case atau operasi. Diagram ini mengilustrasikan bagaimana pesan terkirim dan diterima di antara objek dan dalam sekuensi atau timing apa.

b. Diagram kolaborasi / Collaboration Diagram: serupa dengan diagram rangkaian/sekuensi, tetapi tidak fokus pada timing atau sekuensi pesan. Diagram ini justru menggambarkan interaksi (atau kolaborasi) antara objek dalam sebuah format jaringan.

\section{Diagram State/State Diagram}

a. Diagram state chart: digunakan untuk memodelkan behavior objek khusus yang dinamis. Diagram ini mengilustrasikan siklus hidup objekberbagai keadaan yang dapat diasumsikan oleh objek dan event-event (kejadian) yang menyebabkan objek beralih dari satu state ke state lain.

b. Diagram aktivitas / Activity Diagram: secara grafis digunakan untuk menggambarkan rangkaian aliran aktivitas baik proses bisnis maupun use case. Activity diagram dapat juga digunakan untuk memodelkan action yang akan dilakukan saat sebuah operasi dieksekusi, dan memodelkan hasil dari action tersebut.

\section{Diagram Implementasi}

Diagram implementasi juga memodelkan struktur sistem informasi, yaitu

a. Diagram komponen / Component Diagram : digunakan untuk menggambarkan organisasi dan ketergantungan komponen-komponen software sistem. Komponen diagram dapat digunakan untuk menunjukan bagaimana kode pemrograman dibagi menjadi modul-modul (atau komponen).

b. Diagrampenguraian/Deployment: dig unakan untuk mendeskripsikan arsitektur fisik dalam istilah "node" untuk hardware dan software dalam sistem. Diagram ini menggambarkan konfigurasi komponen-komponen software real-time, prosesor, dan peralatan yang membentuk arsitektur sistem.

\subsubsection{Notasi UML}

Tabel 2.5 Notasi UML

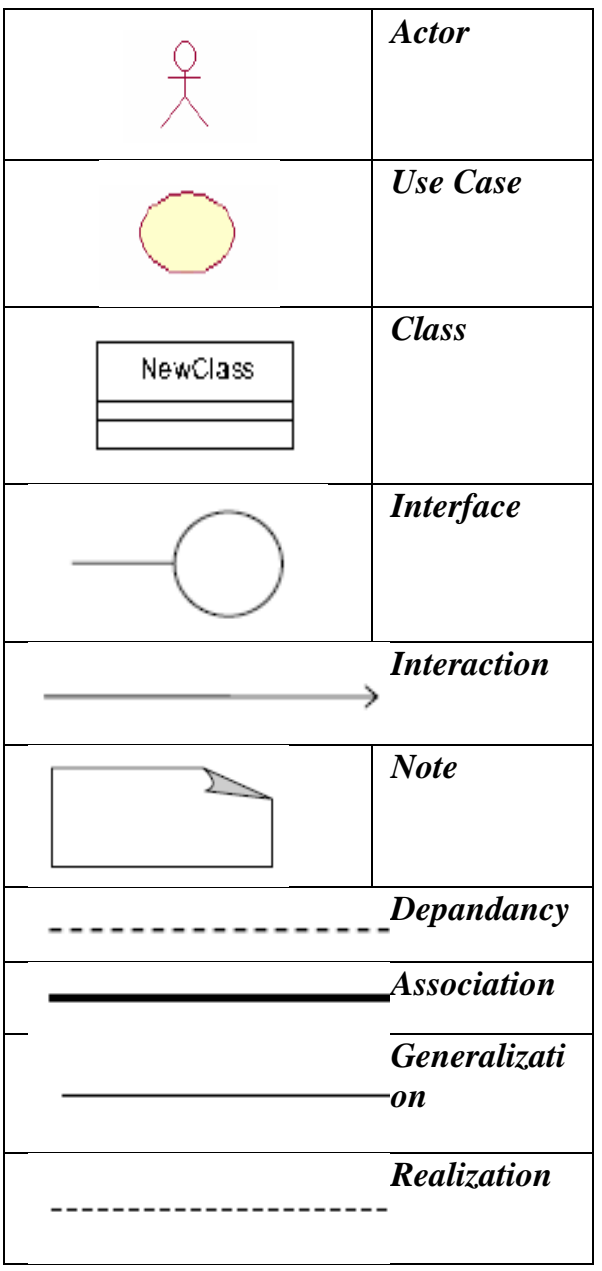

\subsubsection{Keterangan Notasi UML}

\section{Actor}

Actor menggambarkan segala pengguna software aplikasi (user). Actor memberikan suatu gambaran jelas tentang apa yang harus dikerjakan software aplikasi. Sebagai contoh sebuah actor dapat memberikan input kedalam dan menerima informasi dari software aplikasi, perlu dicatat bahwa 
sebuah actor berinteraksi dengan use case, tetapi tidak memiliki kontrol atas use case. Sebuah actor mungkin seorang manusia, satu device, hardware atau sistem informasi lainnya.

\section{Use Case}

Use case menjelaskan urutan kegiatan yang dilakukan actor dan sistem untuk mencapai suatu tuj uan tertentu. Walaupun menj elaskan kegiatan, namun use case hanya menjelaskan apa yang dilakukan oleh actor dan sistem bukan bagaimana actor dan sistem melakukan kegiatan tersebut. Usecase Konkret adalah use case yang dibuat langsung karena keperluanactor. Actor dapat melihat dan berinisiatif terhadapnya. Use-case Abstrak adalah use case yang tidak pernah berdiri sendiri.

\section{Class}

Class merupakan pembentuk utama dari sistem berorientasi obyek, karena class menunjukkan kumpulan obyek yang memiliki atribut dan operasi yang sama. Class digunakan untuk mengimplementasikan interface. Class digunakan untuk mengabstraksikan elemenelemen dari sistem yang sedang dibangun. Class bisa merepresentasikan baik perangkat lunak maupun perangkat keras, baik konsep maupun benda nyata. Notasi class berbentuk persegi panjang berisi 3 bagian: persegi panjang paling atas untuk nama class, persegi panj ang paling bawah untuk operasi, dan persegi panjang ditengah untuk atribut. Atribut digunakan untuk menyimpan informasi. Nama atribut menggunakan kata benda yang bisa dengan jelas merepresentasikan informasi yang tersimpandidalamnya. Operasi menunjukkan sesuatu yang bisa dilakukan oleh obyek dan menggunakan kata kerja.

\section{Interface}

Interface merupakan kumpulan operasi tanpa implementasi dari suatu class. Implementasi operasi dalam interface dijabarkan oleh operasi didalam class.Oleh karena itu keberadaan interface selalu disertai oleh class yangmengimplementasikan operasinya. Interface ini merupakan salah satu cara mewujudkan prinsip enkapsulasi dalam obyek.

\section{Interaction}

Interaction digunakan untuk menunjukkan baik aliran pesan atau informasi antar obyek maupun hubungan antar obyek. Biasanya interaction dilengkapi juga dengan teks bernama operation signature yang tersusun dari nama operasi, parameter yang dikirim dan tipe parameter yang dikembalikan.

\section{Note}

Note digunakan untuk memberikan keterangan atau komentar tambahan dari suatu elemen sehingga bisa langsung terlampir dalam model. Note ini bisa disertakan ke semua elemen notasi yang lain.

\section{Dependency}

Dependency merupakan relasi yang menunj ukan bahwa perubahan pada salah satu elemen memberi pengaruh pada elemen lain. Elemen yang ada di bagian tanda panah adalah elemen yang tergantung pada elemen yang ada dibagian tanpa tanda panah. Terdapat 2 stereotype dari dependency, yaitu include dan extend. Include menunjukkan bahwa suatu bagian dari elemen (yang ada digaris tanpa panah) memicu eksekusi bagian dari elemen lain (yang ada di garis dengan panah).Extend menunjukkan bahwa suatu bagian dari elemen di garis tanpa panah bisa disisipkan kedalam elemen yang ada di garis dengan panah.

\section{Asociation}

Association menggambarkan navigasi antar class (navigation), berapa banyak obyek lain yang bisa berhubungan dengan satu obyek (multiplicity antar class) dan apakah suatu class menjadi bagian dari class lainnya (aggregation). Navigation dilambangkan dengan penambahan tanda panah di akhir garis. Bidirectional navigation menunjukkan bahwa dengan mengetahui salah satu classbisa didapatkan informasi dari class lainnya. Sementara Uni Directional navigation hanya dengan mengetahui class diujung garis association tanpa panah kita bisa mendapatkan informasi dari class di ujung dengan panah, tetapi tidak sebaliknya. Aggregation mengacu pada hubungan has-a, yaitu bahwa suatu class memiliki class lain, misalnya Rumah memiliki class Kamar. 


\section{Generalization}

Generalization menunjukkan hubungan antara elemen yang lebih umum ke elemen yang lebih spesifik. Dengan generalization, class yang lebih spesifik (subclass) akan menurunkan atribut dan operasi dari class yang lebih umum (superclass) atau subclass is superclass . Dengan menggunakan notasi generalization ini, konsep inheritance dari prinsip hirarki dapat dimodelkan.

\section{Realization}

Realization menunj ukkan hubungan bahwa elemen yang ada di bagian tanpa panah akan merealisasikan apa yang dinyatakan oleh elemen yang ada dibagian dengan panah. Misalnya class merealisasikan package, component merealisasikan class atau interface.

\subsubsection{Diagram UML}

\section{Use Case Diagram}

Use case diagram menggambarkan fungsionalitas yang diharapkan dari sebuah sistem. Yang ditekankan adalah "apa" yang diperbuat sistem, dan bukan "bagaimana". Sebuah use case merepresentasikan sebuah interaksi antara aktor dengan sistem. Use case merupakan sebuah pekerjaan tertentu, misalnya login ke sistem, meng- create sebuah daftar belanja, dan sebagainya. Seorang/sebuah aktor adalah sebuah entitas manusia atau mesin yang berinteraksi dengan sistem untuk melakukan pekerjaan-pekerjaan tertentu.

\section{Class Diagram}

Class adalah sebuah spesifikasi yang jika diinstansiasi akan menghasilkan sebuah objek dan merupakan inti dari pengembangan dan desain berorientasi objek. Class menggambarkan keadaan (atribut/properti) suatu sistem, sekaligus menawarkan layanan untuk memanipulasi keadaan tersebut (metoda/fungsi). Class diagram menggambarkan struktur dan deskripsi class, package dan objek beserta hubungan satu sama lain seperti containment, pewarisan, asosiasi, dan lain-lain.

Class memiliki tiga area pokok :

1.Nama (dan stereotype)

\section{Atribut}

3.Metoda

Class dapat merupakan implementasi dari sebuah interface, yaitu class abstrak yang hanya memiliki metoda. Interface tidak dapat langsung diinstansiasikan, tetapi harus diimplementasikan dahulu menjadi sebuah class. Dengan demikian interface mendukung resolusi metoda pada saat run-time. Sesuai dengan perkembangan class model, class dapat dikelompokkan menjadi package . Kita juga dapat membuat diagram yang terdiri atas package .

\section{Hubungan Antar Class}

1. Asosiasi, yaitu hubungan statis antar class . Umumnya menggambarkan class yang memiliki atribut berupa class lain, atau class yang harus mengetahui eksistensi class lain. Panah navigability menunjukkan arah query antar class .

2. Agregasi, yaitu hubungan yang menyatakan bagian ("terdiri atas..").

3. Pewarisan, yaitu hubungan hirarkis antar class . Class dapat diturunkan dari class lain dan mewarisi semua atribut dan metoda class asalnya dan menambahkan fungsionalitas baru, sehingga ia disebut anak dari class yang diwarisinya. Kebalikan dari pewarisan adalah generalisasi.

4. Hubungan dinamis, yaitu rangkaian pesan ( message ) yang di- passing dari satu class kepada class lain. Hubungan dinamis dapat digambarkan dengan menggunakan sequence diagram yang akan dijelaskan kemudian.

\section{Activity Diagram}

Activity diagrams menggambarkan berbagai alir aktivitas dalam sistem yang sedang dirancang, bagaimana masingmasing alir berawal, decision yang mungkin terjadi, dan bagaimana mereka berakhir. Activity diagram juga dapat menggambarkan proses paralel yang mungkin terjadi pada beberapa eksekusi. Activity diagram merupakan state diagram khusus, di mana sebagian besar state adalah action dan sebagian besar transisi di- trigger oleh selesainya state sebelumnya ( internal processing ).

\section{Sequence Diagram}

Sequence diagram menggambarkan interaksi antar objek di dalam dan di sekitar sistem (termasuk pengguna, display, dan sebagainya) berupa message yang digambarkan terhadap waktu. Sequence 
diagram terdiri atar dimensi vertikal (waktu) dan dimensi horizontal (objek-objek yang terkait). Sequence diagram biasa digunakan untuk menggambarkan skenario atau rangkaian langkah-langkah yang dilakukan sebagai respons dari sebuah event untuk menghasilkan output tertentu. Diawali dari apa yang men- trigger aktivitas tersebut, proses dan perubahan apa saja yang terjadi secara internal dan output apa yang dihasilkan.

\section{Kebutuhan Perangkat Keras}

Spesifikasi hardware yang digunakan untuk membuat aplikasi ini adalah:
a. Processor: minimum DualCore
b. Memory :minimum1GB (32bit)
c. Hardisk : minimum 20GB
d. VGA Card
e. Wifi / Modem

\subsubsection{Kebutuhan Perangkat Lunak}

Spesifikasi software yang digunakan untuk membuat aplikasi ini adalah:
a. OS Windows Xp Service Pack 3
b. Local Server XAMPP, sebagai database aplikasi e-Commerce
c. CMS Joomla
d. Macromedia Dreamweaver 8, untuk membangun aplikasi sistem e-Commerce

\subsubsection{Kebutuhan Pengguna}

A. Kebutuhan Brainware:

1.Owner adalah pemimpin dan penanggung jawab tertinggi yang ada di PD Damai Motor. Owner memiliki hak akses sistem seperti menginput daftar barang dan stok update dan melihat laporan keuangan.

2.Admin memiliki hak akses sistem seperti menginput data barang, upload gambar barang, updated stock barang, edit database, maintanance database

B. Kebutuhan Fungsional:

1. User Login,

2. Upload gambar barang beserta stock barang , harga hingga detail barang,

3. Menyimpan data laporan barang yang telah terjual,

4. Merekomendasikan Baranng pada customer

5. Menghapus Daftar barang yang sudah sold / habis,
6. Merubah data stok barang yang tersedia,

7. Melihat hasil penjualan pada PD.Damai Motor

C. Kebutuhan Non Fungsional:

1. Dapat terus dirawat dan dipelihara (maintainability),

2. Efektif dan efisien dalam menggunakan energi dan penggunaannya,

3. Dapat memenuhi kebutuhan yang diinginkan (usability),

4. Dapat mengikuti keinginan pengguna (robust)

5. Dapat mengikuti perkembangan teknologi (dependability),

6. Dapat adaptasi dengan lingkungan yang berbeda,

7. Kemudahan membaca dan memahami struktur perangkat lunak,

8. Ketepatan sistem.

\subsection{Metode Pemilihan Sampel}

Dalam penelitian ini, yang menjadi batasan populasi didalam penelitian ini adalah User, yaitu individu yang menggunakan sistem untuk melakukan fungsi tertentu. Populasi penelitian dari user adalah Seluruh Staff dari PD Damai Motor yang masih aktif sejumlah 15 orang.

\subsection{Metode Pengumpulan Data}

Metode pengumpulan data yang digunakan dalam penelitian ini adalah:

1. Observasi

Metode observasi atau pengamatan merupakan salah satu metode pengumpulan data atau fakta yang cukup efektif. Yang langsung di pandu Oleh Ibu Rismayanthi sebagai staff bagian pencatatan barang barang di PD Damai Motor

2. Wawancara

Metode pengumpulan data dengan cara mengajukan pertanyaan-pertanyaan atau tanya jawab secara langsung kepada pihak tertentu dalam hal membantu pengumpulan data untuk mengetahui permasalahan permasalahan atau proses dalam sistem. Wawancara dilakukan untuk mencari data yang diperlukan dalam penelitian. Dan langsung melakukan wawancara kepada Bp Haryono Selaku Owner di PD Damai Motor

\subsection{Variabel Penelitian}

Menurut Sugiyono (2009:38), variable penelitian pada dasarnya adalah segala sesuatu yang berbentuk apa saja yang ditetapkan oleh 


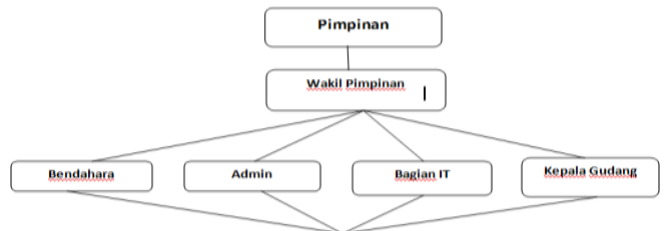

Karyawan

\section{Gambar 2.8. Variable Penelitian}

peneliti untuk dipelajari sehingga diperoleh informasi tentang hal tersebut, kemudian ditarik kesimpulannya

Variabel yang digunakan dalam penelitian ini yaitu variabel bebas dan variabel terikat.

\begin{tabular}{|c|c|c|c|c|c|c|c|}
\hline $\begin{array}{l}\text { Pelang } \\
\text { gan }\end{array}$ & $\begin{array}{l}\mathrm{Si} \\
\mathrm{m}\end{array}$ & $\begin{array}{l}\mathrm{E} \\
N\end{array}$ & $\begin{array}{l}\mathrm{Si} \\
\mathrm{m} \\
\mathrm{x} \\
\mathrm{E} \\
\mathrm{N}\end{array}$ & $\begin{array}{l}\text { A } \\
X\end{array}$ & $\begin{array}{l}\mathrm{Si} \\
\mathrm{m} \\
\mathrm{X} \\
\mathrm{A} \\
\mathrm{X}\end{array}$ & $\begin{array}{l}\mathrm{S} \\
\mathrm{T}\end{array}$ & $\begin{array}{l}\mathrm{Si} \\
\mathrm{m} \\
\mathrm{x} \\
\mathrm{ST}\end{array}$ \\
\hline Jeffri & 0.5 & 2 & 1 & 2 & 1 & - & - \\
\hline Yudi & 1 & - & - & 1 & 1 & 2 & 2 \\
\hline Rio & $\begin{array}{l}0.3 \\
3\end{array}$ & - & - & - & - & 2 & $\begin{array}{l}0.6 \\
6\end{array}$ \\
\hline $\begin{array}{l}\text { Catheri } \\
\text { ne }\end{array}$ & $\begin{array}{l}0.2 \\
5\end{array}$ & 2 & 0.5 & 2 & 0.5 & 1 & $\begin{array}{l}0.2 \\
5\end{array}$ \\
\hline Hans & $\begin{array}{l}0.3 \\
3\end{array}$ & 2 & $\begin{array}{l}0.6 \\
6\end{array}$ & - & - & - & - \\
\hline Hand & 0.5 & - & - & 1 & 0.5 & 2 & 1 \\
\hline Total & & & $\begin{array}{l}2.1 \\
6\end{array}$ & & 2 & & $\begin{array}{l}3.9 \\
1\end{array}$ \\
\hline $\begin{array}{l}\text { Sim } \\
\text { Sum }\end{array}$ & & & $\begin{array}{l}1.0 \\
8\end{array}$ & & $\begin{array}{l}2.2 \\
5\end{array}$ & & $\begin{array}{l}2.0 \\
8\end{array}$ \\
\hline
\end{tabular}

Variabel bebas adalah variabel yang memunculkan varibel terikat, variabel bebas mempengaruhi variable terikat, variabel yang menjadi sebab berubahnya variabel lain.

\subsubsection{Variabel Bebas}

Variabel bebas pada penelitian ini adalah sistem rekomendasi, yaitu: bidang penjualan dan promosi.

\subsubsection{Variabel Terikat} adalah:

Variabel terikat pada penelitian ini

a. Dalam bidang penjualan dan promosi
1. Daftar Stok Barang
2. Jumlah Pembelian
3. Jumlah Stok Barang

\subsection{Teknik Analisis}

Dari Tabel 2.3 didapatkan nilai rekomendasi dari setiap produk untuk Alfan.

Engine memiliki nilai 1.08, Axle memiliki nilai 2.25, dan Steering memiliki nilai 2.08. Produk dengan nilai rekomendasi tertinggi akan lebih diutamakan untuk ditawarkan kepada Alfan

\subsection{Gambaran Umum PD. Damai Motor}

PD Damai Motor adalah salah satu perusahaan yang bergerak di bagian penjualan spare part di Provinsi Lampung, yang berdiri sejak tahun 1988, yang pada pada waktu itu dipimpin oleh Bapak

Haryono Susilo. Penjualan spare part di PD Damai Motor selama ini dilakukan cukup memuaskan dengan pelayanan dating langsung ke tempat pembelian dan melakukan pemesanan , dan transaksi barang, PD Damai Motor juga dalam perjalanan karir nya, di bantu dengan karyawan - karyawan yang professional di bagian nya masing - masing , dari bagaian administrasi sampai ke bagian IT, hingga customer cukup nyaman dalam memesan dan melakukan transaksi

\subsubsection{Perancangan Penelitian}

Didalam penelitian ini, perancangan aplikasi $e$-Commerce menggunakan . Content Management System (CMS) aplikasi web yang berisikantemplate untuk mengelola isi halaman web secara mudah. Penggunaan CMS tidak memerlukan pengetahuan pemrograman web yang handal karena proses instalasi dan cara penggunaannya sudah user friendly Aplikasi yang digunakan adalah Macromedia Dreamweaver. Dengan PHP scripting language

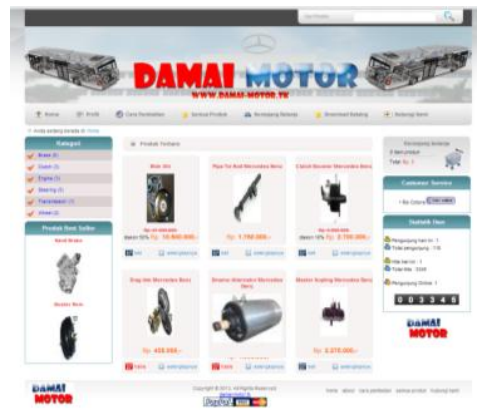

Gambar 3.1 Perancangan Antarmuka 
4.3 Unified Modeling Language

4.3.1 Use Case

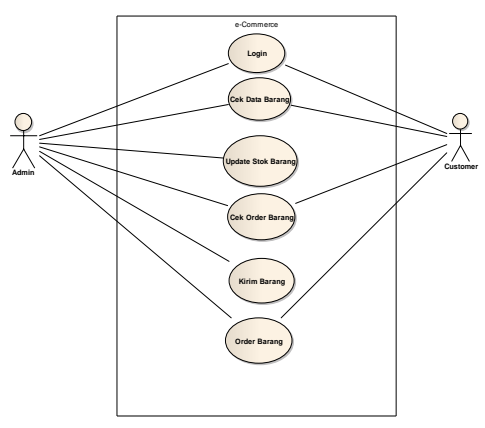

Gambar 3.2Use Case Diagram

Sequence Diagram

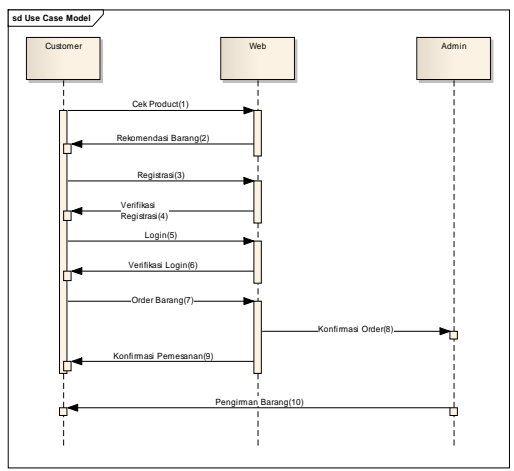

Gambar 3.4 Sequence Diagram

\subsection{Antar Muka Pengguna}

4.4.1 Tampilan Aplikasi E-Commerce Damai Motor

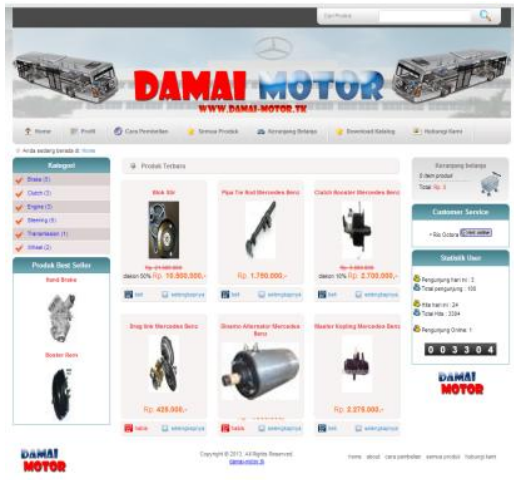

Gambar 4.2 Aplikasi E-Commerce

4.4.2 Tampilan Aplikasi E-Commerce Dengan Sistem Rekomendasi

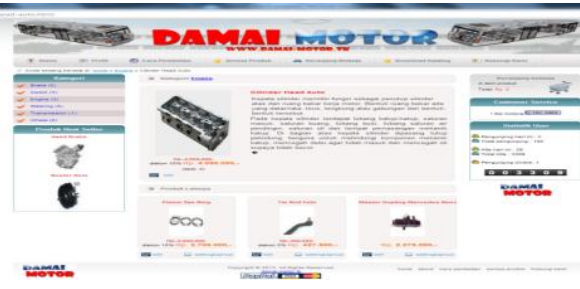

Gambar 4.2 Aplikasi E-Commerce Dengan Sistem Rekomendasi

\subsubsection{Tampilan Shooping Cart}

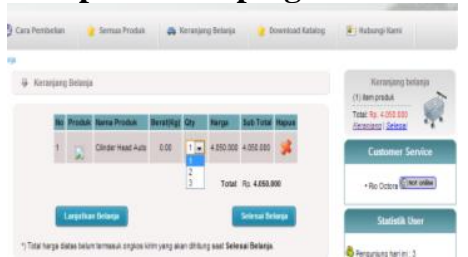

Gambar 4.3 Tampilan Shooping Cart

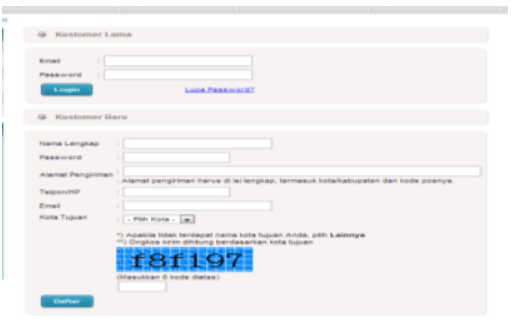

Gambar 4.4 Tampilan Form Pemesanan

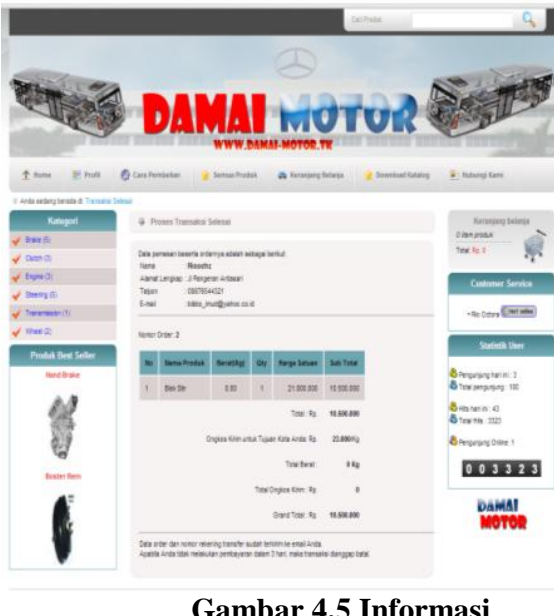

\subsection{Cyclomatic Complexcity}

Cyclomatic Complexity adalah salah satu metode pengujian perangkat lunak yang membutuhkan potongan source code dari sebuah program. Source code tersebut harus dikonversikan ke dalam bentuk graph. Namun, banyak kendala yang diakibatkan dari pengkonversian ini. Salah satu kendalanya adalah sulitnya menentukan node dan edge dari program tersebut.

$\mathrm{V}(\mathrm{G})=\mathrm{E}-\mathrm{N}+2$ 
$\mathrm{V}(\mathrm{G})=\mathrm{P}+1$

$\mathrm{V}(\mathrm{G})=12-10+2$

$\mathrm{V}(\mathrm{G})=3+1$

$\mathrm{V}(\mathrm{G})=4$

$\mathrm{V}(\mathrm{G})=4$

Keterangan :

$\mathrm{V}(\mathrm{G})$ : Cyclomatic Complexity;

$\mathrm{E}$ : banyaknya edge (panah);

$\mathrm{N}$ : banyaknya node (lingkaran);

$\mathrm{P}$ : banyaknya predicate node.

\subsection{Implementasi}

Implementasi Program website e-Commerce di PD Damai Motor membagi tahapan menjadi beberapa bagian yaitu sebagai berikut :
A. Lakukan Instalasi CMS pada Webhosting / Website damai-motor.tk
B. Lakukan Koneksi database langsung ke Website damai-motor.tk
C. Lakukan Penambahan Script PHP / CMS ke Website damai-motor.tk
D. Lakukan Penambahan Product Langsung di Website
E. Lakukan Akses Ke damai-motor.tk

\section{Kesimpulan}

Berdasarkan tugas akhir tentang aplikasi $E$ Commerce dengan sistem rekomendasi ItemBased Collaborative Filtering yang telah di uraikan dari Bab I sampai Bab IV, maka dapat di ambil kesimpulan bahwa berdasarkan hasil survey, aplikasi $E$ Commerce dengan sistem rekomendasi ItemBased Collaborative Filtering dapat membantu mengelola data pelanggan , membantu memberikan informasi kepada pelanggan , mempermudah pemilihan items dengan barang yang di rekomendasikan oleh sistem memudahkan pemesanan kepada pelanggan , serta memperluas market penjualan

\section{Saran}

Penulis mengharapkan penelitian ini dapat dikembangkan lebih lanjut diantaranya:

1. Aplikasi ini dapat di akses secara mobile

2. pembayaran dapat dilakukan dengan paypal dan kartu kredit

\section{Daftar pustaka}

1) Admovicious \& Tuzhliin , 2005, Towards the Next Generation of Recommender : A. Survey of The State Of The Art And Possible Extensions.

2) Amsyah , 2000 , Manajemen Informasi , Jakarta:Gramedia
3) Bently,D \& Whitten, 2007, Metode Desain \& Analisis Sistem Edisi 6 , Mc Graw Hill Education, Penerbit ANDI

4) Bogers \& Bosch , 2007, Comparing and evaluating information retrieval algorithms for news recommendation, in the Proceedings of the 2007 ACM Confrence, Minneapolis, MN , USA. RecSys"07. ACM, New York

5) Christanti, Meliana , Christian Hadiguna 2011 , Aplikasi ECommerce dengan Sistem Rekomendasi Berbasis Collaborative Filtering, Universitas Kristen Maranatha, Bandung

6) DevZone, 2011, Building E-Commerce Application, England

7) Dyche , 2004 , The Customer Relationship Management Handbook, Seventh Edition, USA, Addison, Wesley

8) Ekstrand , Michael D, John T. Riedl , \& Jospeh A. Konstan , 2010, Collaborative Filltering Recomender, Austria

9) Galih, Tidian , Aris Sugiharto \& Mustafid , 2010 , Rancang Bangun Portal E-Commerce Semarang Hanydcraft beriorientasi Objek, Universitas Diponogoro Semarang

10) Gao,Yun , 2005, Encyplodedia of Information Science and Technology, England

11) Ghu, Junzhong, Ren, Lei , Xia , Wei Wei , 2011, An Item-Based Collaborative Filtering Approach based on Balanced Rating Prediction, East China Normal University : Shanghai, China

12) Henderi , 2007 , Analysis and Design System With Unified Modeling Language ( UML ), STMIK Raharja , Tanggerang

13) L Sebastia , et al , 2009 , Recomender System, New York

14) Nugroho , $2006, e$-Commerce Memahami perdagangan modern di dunia Maya, Informatika , Bandung

15) P,Baudsich , 2000 , Joining Collaborative and content-based filtering. In Intergrated Publication and Information Systems Institue IPSI

16) Qing , Li \& Kim Byeong Man, 2002 , An Approach for Combining Contentbased and Collaborative Fillters, Departement of Science, Kumoh National Institute of Technology 
17) R, Burke , 2007 , Hybrid Recomender systems, In Proceedings of The Adaptive Web

18) Sawyer, 2001, Internal auditing , McGraw Hill , New York, USA

19) Schafer, dkk,2007, Collaborative Filltering , EGC Penerbit Buku Kedokteran Jakarta
20) Xu, Guandong, hang, Yanchun , \& Li m Lin ( 2010 ). Web mining and Social Networking New York: Springer

21) Whitten, L.J. et.al, 2004 . Method Design And System Analysis.. Mc Graw-Hill International.

22) Winarko , Wiranto 2010 , Konsep Multicriteria Collaborative Filltering untuk perbaikan Rekomendasi, Universitas Gajah Mada, Yogyakart. 